\title{
Study of The Abundance and Characteristics of Microplastic Contamination in The Fish of Capture Results of Fishermen in The Lake Towuti Waters,
}

\section{East Luwu, South Sulawesi}

\author{
Muhammad Amri Yusuf*, Akbar Tahir** \\ * Magister Programme of Fisheries Science, Faculty of Marine Science and Fisheries, Hasanuddin University, Makassar, Indonesia \\ ** Faculty of Marine Science and Fisheries, Hasanuddin University, Makassar, Indonesia
}

DOI: 10.29322/IJSRP.11.07.2021.p11593

http://dx.doi.org/10.29322/IJSRP.11.07.2021.p11593

\begin{abstract}
Microplastics $(<5 \mathrm{~mm})$ are a serious threat, both to aquatic organisms and to humans directly. This is due to microplastics in waters can absorb various toxic substances, so as consuming aquatic organisms that have been contaminated with microplastics can endanger human health. So far, research on microplastics has generally been carried out in marine waters, but in this research it was conducted in fresh waters, especially on fish caught by fishermen which are often consumed by local communities in the waters of Towuti Lake, East Luwu, South Sulawesi. Sampling was obtained from fishermen, namely: 15 fish of butini (Glossogobius matanensis), 15 fish of tilapia (Oreochromis niloticus), 15 fish of snakehead (Channa striata), 11 fish of climbing perch (Anabas testudineus) and 15 fish of flowerhorn (Cichlasoma timaculatum). Identified, then measured body weight and total length. The gastrointestinal tract was dissected and taken then soaked in $20 \% \mathrm{KOH}$ for 14 days, then observed microplastics with a stereo microscope. The result is an abundance of 4.20-9.60 items/individual, five color variants, namely: blue dominates, black, transparent, red and green, two form variants, namely: line dominates and fragments. The dominance of the blue items (34.09-67.52\%) is thought to be due to the availability of a lot in general in the waters, while the dominance of the line shape (75.21-95.83\%) is thought to be because the shape of the line resembles the shape of prey from fish such as phytoplankton and zooplankton.
\end{abstract}

Keywords: Microplastics, toxic substances, lake towuti, fish consumption, community

\section{INTRODUCTION}

$\mathrm{T}$ he modern era gives rise to a variety of activities carried out by humans, one of which is the use of plastic in aspects of daily life, both on a small and large scale. Waste from the use of plastic is currently the object of attention in terms of environmental pollution, both in terrestrial and aquatic ecosystems. Globally, in 2010 plastic waste approached the amount of 13 million metric tons (MT) from more than 190 countries in the world that entered aquatic ecosystems (Jambeck et al., 2015). Plastic waste found in aquatic ecosystems varies in size, all of which vary in size to pose a threat to waters globally (Tahir et al., 2019). In all the variations in the size of plastic waste, those with a size of $<5 \mathrm{~mm}$ are classified as microplastics (Choi et al., 2019; GESAMP, 2019). Microplastics that are freely dispersed in waters come from plastic waste that is fragmented, degraded, into smaller pieces/plastic debris (Masura et al., 2015; Zhang et al., 2020). This can be a problem for some aquatic organisms, because they suspect these microplastics as safe prey for consumption (Masura et al., 2015).

Starting from the activities of prey to predator on aquatic organisms, ranging from small organisms to large organisms, according to the trophic level and culminate in food consumption in humans. In fact, several studies have found that microplastics are harmful to health, both in aquatic animals (Wang et al., 2019) and in humans (Wang et al., 2018). This is in accordance with the research of Wang et al. (2018) which states that microplastics (MPs) can absorb various toxic chemicals that can certainly harm the health of aquatic animals, such as PCB, PAH, HCH, DDT. So that consuming aquatic animals that have been contaminated with microplastics can endanger human health.

However, several studies showing microplastic pollution have focused on aquatic animals in marine ecosystems, while microplastic pollution in freshwater ecosystems and their organisms is still lacking (Basseling et al., 2016; Wang et al., 2019). Microplastic pollution, apart from occurring in marine, estuary and river ecosystems, can also occur in lakes (Yuan et al., 2019; Yin et al., 2019; Wicaksono et al., 2020; Pleiter et al., 2020; Alfonso et al., ., 2020; Jiang et al., 2020; Taha et al., 2021), whereas research on 
microplastic pollution in lakes has never been conducted. The occurrence of microplastic pollution in lakes is based on various reasons (Yuan et al., 2019), namely: hydrodynamics, topography, fishing activities, agricultural activities and household waste.

The Lake of Towuti is one of the lakes located in East Luwu Regency, South Sulawesi Province and also one of five lakes included in the Malili Lake complex, namely: Matano Lake, Mahalona Lake, Towuti Lake, Wawantoa Lake and Masapi Lake. The Lake of Towuti is one of the large lakes in Indonesia, the second largest after Toba Lake (Wijaya et al., 2009). It has a surface area of about $560 \mathrm{~km} 2$, the depth of the lake is up to $203 \mathrm{~m}$ and is 293 above sea level (Haffner et al., 2001).

Several problems related to the potential for pollution in the waters of Towuti Lake, namely: household waste along with the increasing population, capture fisheries activities, agriculture, industrial and mining waste, poses a threat to aquatic animals in the waters of Towuti Lake (Wijaya et al., 2009). as well as a threat to the community who will consume aquatic animals (caught fish) originating from the waters of Towuti Lake. Based on the description above, it is necessary to conduct research on the study of the presence and abundance of microplastic pollutants in fish captured in the waters of Towuti Lake.

\section{METHOD}

Fish samples were taken from the capture of fishermen using trawls or other types of fishing gear, in the fishing area of Towuti Lake (Points H, G and C in Figure 1). In general, the fish samples taken were the species of fish commonly consumed by the communities of Towuti Lake.

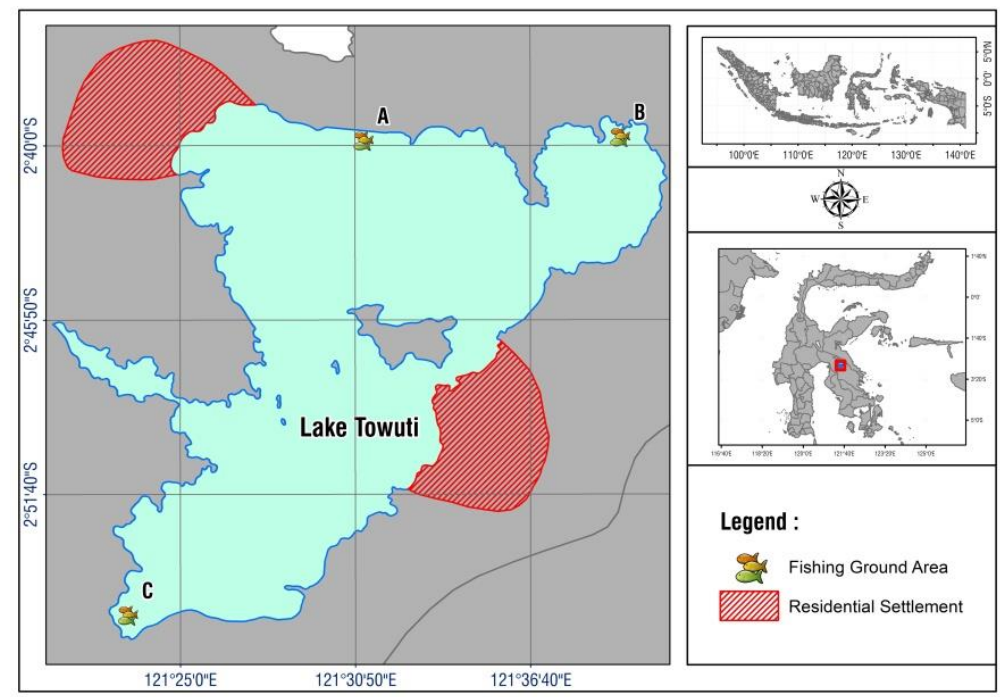

Figure 1. Sampling Location, Lake Towuti, East Luwu, South Sulawesi

The capture fish were then measured for body weight, total length and standard length and then identified the species. The sample was then dissected and the entire Gastrointestinal Tract (GIT) was taken for microplastic analysis in the laboratory.

The GIT sample was immersed in a $\mathrm{KOH}$ solution of $20 \%$ (200 g KOH crystal + 1L aquadest) was added to the sample 3 times the sample volume and left for 14 days at room temperature until the organic particles in the sample were destroyed (Foekema et al., 2013; Lusher et al. ., 2016). The sample was then poured into a petri dish gradually and observed using a Stereo Microscope. The microplastic samples found were then identified by color, shape, size and number.

\section{RESULTS}

Now The data obtained from the results of this research, namely: fish identification data and sample size in fish, while the test results of microplastic data on fish samples can be viewed from: the abundance of microplastics, the proportion of microplastic color and the proportion of microplastic shapes.

\section{Identification and Size of Fish Sample}

There are several species of fish captured from fishermen, namely: butini fish (Glossogobius matanensis), tilapia (Oreochromis niloticus), snakehead fish (Channa striata), climbing perch (Anabas testudineus) and flowerhorn (Cichlasoma timaculatum). This species of fish is the daily food of the communities around Towuti Lake. Regarding the identification data on these fish species, it can be seen in Table 1, while the size data can be seen in Table 2.

Table 1. Fish Sample Identification Data.

\begin{tabular}{lllc}
\hline \multicolumn{1}{c}{ Spesies } & \multicolumn{1}{c}{ Feeding Habit } & \multicolumn{1}{c}{ Food } & Zone \\
\hline G. matanensis & Carnivore (Mamangkey, 2010) & Small fish & Demersal \\
O. niloticus & Herbivore (Mamangkey, 2010) & Phytoplankton & Pelagic \\
C. striata & Carnivore (Fitriani et al, 2011) & Fish, crustaceans & Demersal \\
\hline
\end{tabular}




\begin{tabular}{lllc}
\hline A. testudineus & Carnivore (Fitriani et al, 2011) & Small shrimp, fish larvae & Demersal \\
C. trimasculatum & Carnivore (Hedianto, 2018) & Small fish, zooplankton & Pelagic \\
\hline
\end{tabular}

Table 2. Fish Sample Size Data

\begin{tabular}{lccc}
\hline \multicolumn{1}{c}{ Spesies } & Average Total Length $(\mathbf{c m})$ & Average Total Weight $(\mathbf{g})$ & \% Contamination \\
\hline G. matanensis & $20.27 \pm 1.42$ & $82.61 \pm 15.90$ & $100 \%$ \\
O. niloticus & $18.87 \pm 0.94$ & $150.07 \pm 25.31$ & $100 \%$ \\
C. striata & $25.91 \pm 1.84$ & $165.63 \pm 43.01$ & $93 \%$ \\
A. testudineus & $14.7 \pm 1.27$ & $61.20 \pm 21.67$ & $91 \%$ \\
C. trimasculatum & $13.34 \pm 1.14$ & $49.04 \pm 10.65$ & $93 \%$ \\
\hline
\end{tabular}

\section{Data Test Results}

1. Abundance of Microplastics in Fish Samples

The results of the test of microplastic abundance data in fish samples are presented in Figure 2.

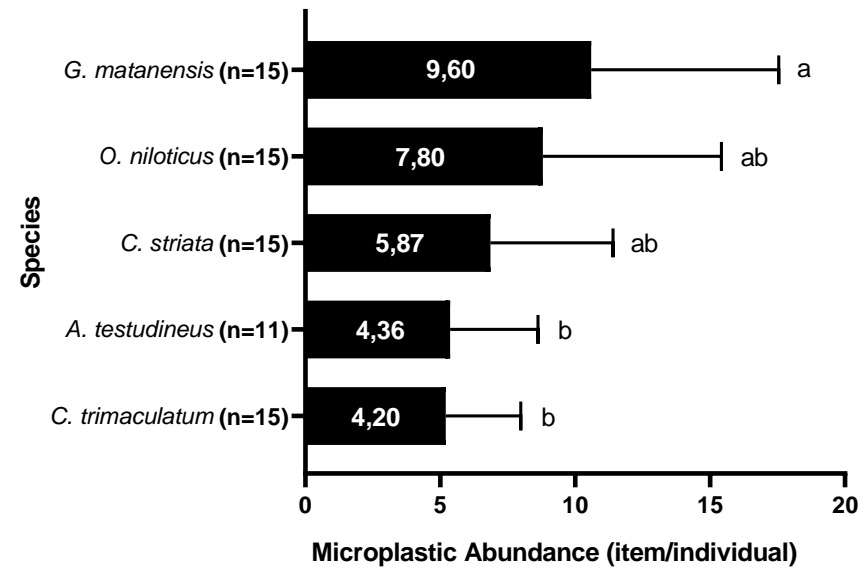

Figure 2. Abundance of Microplastics in Fish Samples (items/individuals), different superscript letters show significant differences based on the one-way ANOVA test $(\mathrm{p}<0.05)$, (n) indicates the number of fish samples.

Based on the results of the analysis of variance, it was shown that the abundance of microplastics in the samples of butini fish (G. matanensis) was significantly different from snakehead fish (A. testudineus) and flowerhorn (C. trimaculatum) (p <0.05). Butini fish (G. matanensis) is the species of fish that contains the most microplastic pollution compared to the other four fish species.

2. Proportion of Microplastic Color in Fish Samples

The proportion of microplastic color data is presented in Figure 3.

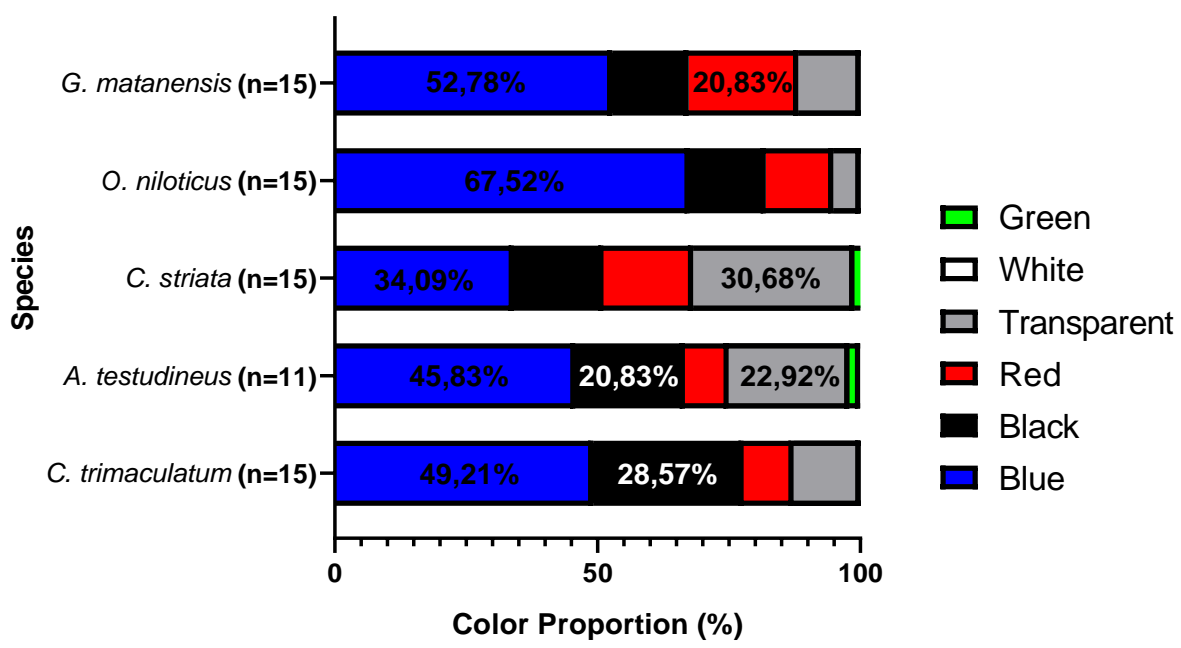


Figure 3. Proportion of Microplastic Color in Fish Samples, (n) shows the number of fish samples

The results of observations made on fish samples found five color variants, namely: blue, black, transparent, red and green. In all the colors found, blue is the dominant color $(34.09 \%-67,52 \%)$. Microplastic particles with red, black and transparent colors consistently appeared in each fish species.

3. Proportion of Microplastic Forms in Fish Samples

Data on the proportion of microplastics in fish samples are presented in Figure 4.

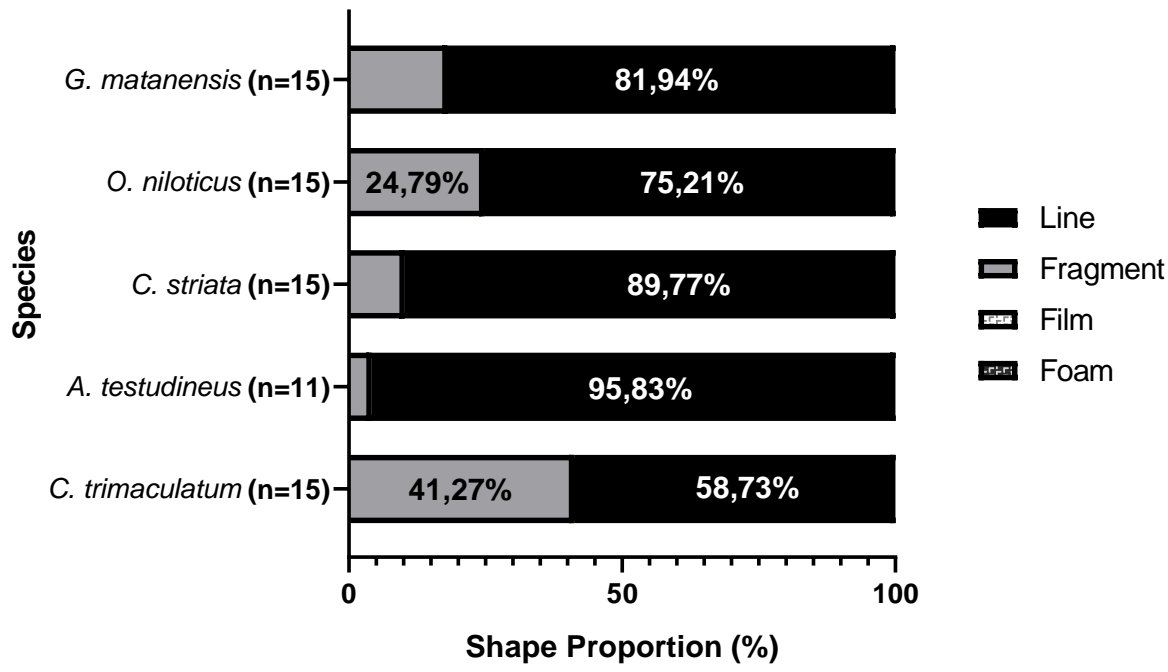

Figure 4. Proportion of Microplastic Forms in Water Samples, (n) shows the number of fish samples

The results of observations made on the sample found two variants of shape, namely: line and fragment. In the two forms found, line is the dominant form (75.21\%-95.83\%). Microplastic observations in fish samples, obtained two shapes and several colors of microplastics, namely (Figure 5):

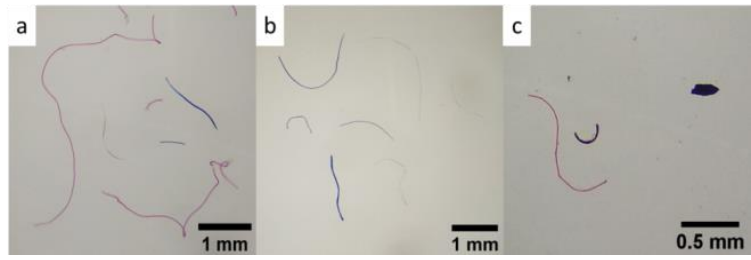

Figure 5. Shape and Color of Microplastics in Fish Samples, (a, b) red line, blue line and (c) blue fragment

\section{DISCUSSION}

\section{Microplastic Abundance}

The abundance of microplastics varies in the digestive tract of fish in several species. The abundance of microplastics in Butini fish (G. matanensis) was significantly different from the abundance of microplastics in Climbing Perch (A. testudineus) and Flowerhorn (C. trimaculatum) but not significantly different from Tilapia (O. niloticus) and Snakehead Fish (C. striata ). Each abundance value were: Butini Fish $(9.60 \pm 6.947)$, Tilapia $(7.80 \pm 6.625)$, Snakehead Fish $(5.87 \pm 4.533)$, Climbing Perch $(4.36 \pm$ $3.264)$ and Flowerhorn $(4.20 \pm 2.783)$. In this research, the value of the abundance of microplastics in fish samples was higher than that of $\mathrm{Wu}$ et al. (2020) which is $0.43 \pm 0.69$ items/individual. All fish samples consisting of five species are fish that are often consumed by the surrounding community. So that fish of the same species that have a high potential to contain microplastics, will most likely be able to threaten human health as consumers (Wang et al., 2018; Wu et al., 2020).

The high value of the abundance of microplastics in butini fish (9.60 items/individual) is thought to be due to the role of butini fish as the peak of the trophic level. Butini fish have a eating habit by preying on small fish and other fish so that they are classified as carnivorous fish, while for the location of their life, this fish is classified as a fish that tends to be at the bottom of the waters (Mamangkey, 2010). The existence of butini fish in Towuti Lake has an important role, besides being one of the consumption fish with animal protein sources, it is also an important economic value for the community.

The abundance value of butini fish was followed by tilapia ( 7.80 items/individual). Tilapia is one of the introduced fish in Towuti Lake, but with a high reproductive rate so that the population is quite large and even begins to threaten the existence of other 
species in the waters of Towuti Lake. Its life habit is in the column or on the surface of the waters, while for its eating habits these fish consume phytoplankton, zooplankton, etc. so that these fish are classified as omnivorous fish that tend to be herbivores, characterized by long fish intestines and litter from the intestines (Mamangkey, 2010). The eating habits of tilapia which are classified as omnivores tend to be herbivores, they also have the opportunity to consume available food in the waters without microplastic particle contamination.

Furthermore, after tilapia with the second highest abundance value, there was snakehead fish with the third highest microplastic abundance value (5.87 items/individual). Snakehead fish is a species of fish that lives on the bottom of the waters, if the dry season is prolonged, snakehead fish can survive in moist soil by relying on the ability of its additional breathing apparatus (labyrinth). The eating habit of snakehead fish is classified as a carnivorous fish, because it preys on small fish and can even prey on its own herd with its cannibalistic nature (Liana et al, 2020). Sources of microplastics in snakehead fish, apart from the waters, are thought to be obtained directly from prey on other fish or similar fish of their size.

Then there is climbing perch with the fourth highest microplastic abundance value (4.36 items/individual). The existence of climbing perch in Towuti Lake is not as popular as butini fish, tilapia, snakehead fish and flowerhorn fish, but it remains a consumption fish for the community. Its existence is not the main choice, but a small part of the community still consumes it.

Climbing perch are fish that are often on the bottom of the waters with eating habits classified as omnivorous fish but tend to be carnivores because there are many species of animals found in their intestines compared to plant species. One of the abilities of the climbing perch is to be able to survive in waters with low oxygen conditions, this is because the climbing perch are able to directly take up oxygen on the surface with the help of an additional breathing apparatus called labyrinth (Fitriani et al., 2011). The condition of the climbing perch with the fourth highest abundance value or can be said to be lower than the other three fish is probably due to the high level of selectivity in determining food and its frequent living habits at the bottom of the waters.

Then after climbing perch, there was flowerhorn fish with the lowest abundance value compared to the other four species (4.20 items/individual). Flowerhorn fish is a fish whose life habits are almost similar to tilapia, which likes to be in the column and on the surface of the water, while for its eating habits this fish is classified as an omnivorous fish as well. However, unlike tilapia, this flowerhorn fish tends to be carnivorous, characterized by the presence of bones from the flowerhorn fish intestine. The bones are thought to be the result of preying on small fish in the waters. The flowerhorn fish in the waters of Towuti Lake are thought to be due to fish migration activities from Matano Lake (Hedianto, 2018).

The low abundance value of flowerhorn fish is probably due to the relatively low population (minority) in the waters of Towuti Lake, so competition for food in the waters is more passive with other fish.

\section{Microplastic Color Proportion}

The proportion of microplastic color in fish samples was dominated by blue. Several studies have also stated that in general, microplastics with blue particles are the most dominating and most commonly found in fish (Possatto et el., 2011; Lusher et al., 2016 Vendel et al., 2017 Ferreira et al., 2018; Zhang et al., 2019; Wu et al., 2020). Blue microplastic particles can be found in paint compositions, in packaging compositions that are often used by the packaging industry and are generally sourced from anthropogenic activities (Lewis, 2004; Cauwenberghe et al., 2013; Dantas et al., 2020). Then Dantas et al. (2020) in their research stated that the availability of blue-colored microplastics that dominate is probably due to its availability in abundant waters compared to other colored microplastic particles.

In this research, it is possible that the abundance of blue microplastic particles is the most dominating in the waters. So that the high abundance of blue microplastic particles in fish samples, may be due to this.

\section{Proportion of Microplastic Shape}

The proportion of microplastic forms in the fish samples found was dominated by the line shape and followed by the fragment shape with all the colors found. In the research of Dantas et al. (2020) Microplastic particles with the shape of a line are the most commonly found in fish. Microplastic particles with a line shape are very misleading for fish, because the shape of the line is very similar to the food they will prey on (Masura et al., 2015), while the alleged source of microplastic with a line shape can come from the activities of fishermen catching fish with fishing gear used as, trawl nets, ropes, etc. (Wu et al., 2020).

In this research, the abundance of microplastics in the form of lines in fish was higher than that of microplastics in the form of fragments. It may be estimated that the presence of line-shaped microplastics greatly deceives fish in the waters with a shape that resembles the shape of their prey.

\section{CONCLUSION}

Fish captured by fishermen, which are often consumed by the community, are contaminated with microplastic particles. The abundance of microplastic contamination in captured fish ranged from 4.20 to 9.60 items/individual. The blue particle and the shape of the particle line are the most dominating found in the fish samples.

\section{REFERENCES}

[1] Alfonso, M.B., Scordo, F., Seitz, C., Mansretta, G.M.M., Ronda, A.C., Arias, A.H., Tomba, J.P., Silva, L.I., Perillo, G.M.E., Piccolo, M.C. 2020. First evidence of microplastics in nine lakes across Patagonia (South America). Science of the Total Environment 733 (2020) 139385. https://doi.org/10.1016/j.scitotenv.2020.139385 
[2] Besseling, E., Joris T.K., Quik, Sun, M., Albert, A., Koelmans. 2016. Fate of nano- and microplastic in freshwater systems: A modeling study. Environmental Pollution xxx (2016) 1-9. http://dx.doi.org/10.1016/j.envpol.2016.10.001

[3] Cauwenberghe, L.V., Vanreusel, A., Mees, J., Janssen, C.R. 2013. Microplastic pollution in deep-sea sediments. Enviromental Pollution 182 (2013) $495-499$. http://dx.doi.org/10.1016/j.envpol.2013.08.013

[4] Choi, J.S., Hong, S.H., Park, J.W. 2019 . Evaluation of microplastic toxicity in accordance with different sizes and exposure times in the marine copepod Trigriopus japonicas. Marine Environmental Research. https://doi.org/10.1016/j.marenvres.2019.104838

[5] Dantas, N.C.F.M., Duarte, O.S., Ferreira, W.C., Ayala, A.P., Rezende, C.F., Feitosa, C.V. 2020. Plastic intake does not depend on fish eating habits: Identification of microplastics in the stomach contents of fish on an urban beach in Brazil. Marine Pollution Bulletin 153 (2020) 110959. https://doi.org/10.1016/j.marpolbul.2020.110959

[6] Ferreira, G.V.B., Barletta, M., Lima, A.R.A., Morley, S.M., Justino, A.K.S., Costa, M.F. 2018. High intake rates of microplastics in a Western Atlantic predatory fish, and insights of a direct fishery effect. Enviromental Pollution 236 (2018) 706-717. https://doi.org/10.1016/j.envpol.2018.01.095

[7] Fitriani, M., Muslim, Jubaedah, D. 2011. Ecology of Climbing Perch (Anabas testudineus) in the waters of Rawa Banjiran Indralaya. Agria. Vol. 7. No. 1, 33-39.

[8] GESAMP. (2019). Guidelines or the monitoring and assessment of plastic litter and microplastics in the ocean. Kershaw P.J., Turra A., Galgani F. (Eds.), (IMO/FAO/UNESCO-IOC/UNIDO/WMO/IAEA/UN/UNEP/UNDP/ISA Joint Group of Experts on the Scientific Aspects of Marine Environmental Protection. Rep. Stud. GESAMP No. 99, 130p.

[9] Haffner, G. D., Hehanussa, P.E., Hartoto, D.I. 2001. The biology and physical processes of large lake of Indonesia. Backhuys. Leiden. 183-194.

[10] Hedianto, D.A., Sentosa, A.A., Satria, H. 2018. Reproductive aspects of hybrid flowerhorn fish as invasive foreign fish in Matano Lake, South Sulawesi. Pomfret. 10 (2) August 2018: 85-98. http://ejournal-balitbang.kkp.go.id/index.php/bawal.

[11] Jambeck, J.R., Geyer, R., Wilcox, C., Siegler, T.R., Perryman, M., Andrady, A., Narayan, R., Law, K.L., 2015. Plastic waste inputs from land into the ocean. Science. Vol. 347, 768-771. https://doi.org/10.1126/science.1260352

[12] Lewis, P.A. 2004. Organic Colorants. Coloring of Plastics: Fundamentals 0-471-13906-8.

[13] Liana, Asriyana, Irawati, N. 2020. Eating Habits of Snakehead Fish (Channa striata) in the waters of Rawa Aopa Watumohai, Pewutaa Village, Angata District, The Regency of South Konawe. Journal of Aquatic Resources Management 5(3): 148-156.

[14] Lusher, A.L., Welden. N.A., Sobral, P., Cole, M. 2016. Sampling, isolating and identifying microplastics ingested by fish and invertebrates. Royal Society of Chemistry. http://www.rsc.org/methods

[15] Mamangkey, J.J. 2010. Biopopulation of endemic butini fish (Glossogobius matanensis) in Towuti Lake, South Sulawesi. Graduate School. Bogor Agricultural University.

[16] Masura, J., Baker, J., Foster, G., Arthur, C., Herring, C. 2015. Laboratory Methods for the analysis of microplastics in the marine environment: Recommendations for quantifying synthetic particles in water and sediments. NOAA Technical Memorandum NOS-OR\&R-48

[17] Plieiter, M.G., Velazquez, D., Edo, C., Carretero, O., Gago, J., Sola, A.B., Hernandez, L.E., Yousef, I., Quesada, A., Leganes, F., Rosal, R., Pinas, F. 2020. Fibers spreading worldwide: Microplastics and other anthropogenic litter in an Arctic freshwater lake. Science of the Total Environment 722 (2020) 137904 https://doi.org/10.1016/j.scitotenv.2020.137904

[18] Possatto, F.E., Barletta, M., Costa, M.F., Sul, J.A.I.D., Dantas, D.V. 2011. Plastic debris ingestion by marine catfish: An unexpected fisheries impact. Marine Pollution Bulletin 62 (2011) 1098-1102. http://dx.doi.org/10.1016/j.marpolbul.2011.01.036

[19] Taha, Z.D., Amin, R.M., Anuar, S.T., Nasser, A.A.A., Sohaimi, E.S. 2021. Microplastics in seawater and zooplankton: A case study from Terengganu estuary and offshore waters, Malaysia. Science of The Total Enviroment. Vol. 786 (2021) 147466. https://doi.org/10.1016/j.scitotenv.2021.147466

[20] Tahir, A., Taba, P., Samawi, M.F., Werorilangi, S. 2019.. Microplastics in water, sediment and salts from traditional salt producing ponds. Global Journal Environmental Science Management. 5(4): 431-440, Autumn 2019. http://doi.org/10.22034/gjesm.2019.04.03

[21] Vendel, A.L., Bessa, F., Alves, V.E.N., Amorim, A.L.A., Patricio, J., Palma, A.R.T. 2017. Widespread microplastic ingestion by fish assemblages in tropical estuaries subjected to anthropogenic pressures. Marine Pollution Bulletin. http://dx.doi.org/10.1016/j.marpolbul.2017.01.081

[22] Wang, F., Wong, C.S., Chen, D., Lu, X., Wang, F., Zeng, E.Y. 2018. Interaction of toxic chemicals with microplastics: A critical review. Water Research. https://doi.org/10.1016/j.watres.2018.04.003

[23] Wang, W., Ge, J., Yu, X. 2019. Bioavailability and toxicity of microplastics to fish species: A review. Ecotoxicology and Environmental Safety. https://doi.org/10.1016/j.ecoenv.2019.109913

[24] Wicaksono, E.D., Werorilangi, S., Tahir, A. 2020. The influence of weirs on microplastic fate in the riverine environment (case study: Jeneberang River, Makassar City, Indonesia). MARSAVE. Earth and Enviromental Science 763 (2021) 012054. http://doi:10.1088/1755-1315/763/1/012054

[25] Wijaya, D., Samuel, Masak, P.R.P. 2009. Study of water quality and production potential of fish resources in Towuti Lake, South Sulawesi. Pomfret. Vol. 2 No. 6 December 2009: 291-297.

[26] Wu, J., Lai., M., Zhang, Y., Li, J., Zhou, H., Jiang, R., Zhang, C. 2020. MIcroplastics in the digestive tract of commercial fish from the marine ranching in east China sea, China. Case Studies in Chemical and Enviromental Engineering. https://doi.org/10.1016/j.cscee.2020.100066

[27] Yin, L., Wen, X., Du, C., Jiang, J., Wu, L., Zhang, Y., Hu, Z., Hu, S., Feng, Z., Zhou, Z., Long, Y., Gu, Q. 2019. Comparison of the abundance of microplastics between rural and urban areas: A case study from East Dongting Lake. Chemosphere. https://doi.org/10.1016/j.chemosphere.2019.125486

[28] Yuan, W., Liu, X., Wanga, W., Di, M., Wang, J. 2019. Microplastic abundance, distribution and composition in water, sediments and wild fish from Poyang Lake, China. Ecotoxicology and Environmental Safety. https://doi.org/10.1016/j.ecoenv.2018.11.126

[29] Zhang, Z., Wu, H., Peng, G., Pei, X., Li, D. 2020. Coastal ocean dynamics reduce the export of microplastics to the open ocean. Science of the Total Environment https://doi.org/10.1016/j.scitotenv.2020.136634

\section{AUTHORS}

First Author - Muhammad Amri Yusuf, Master Programme Student, Hasanuddin University, muhammad.amriyusuf@yahoo.co.id Second Author - Akbar Tahir, Lecturer, Faculty of Marine Science and Fisheries, akbartahir.unhas@gmail.com

Correspondence Author - Muhammad Amri Yusuf, muhammad.amriyusuf@yahoo.co.id, ibn.suardimasyitah@gmail.com, $+6282393333028$ 